\title{
Rural Entrepreneurship: An Insight Into Impeding Factors Influencing Micro-Entrepreneurial Growth
}

\author{
Sunday Samson Babalola, Ph.D., University of Venda, South Africa
}

Albert Tchey Agbenyegah, Ph.D., Durban University of Technology, South Africa

\begin{abstract}
The call for the growth of successful entrepreneurial activities across the globe raised the need to determine the influencing factors affecting micro-entrepreneurial growth. Hence, this study adopted a cross-sectional survey design to examine determinants of micro-entrepreneurial growth among micro-entrepreneurs. Two hundred and eighty-two micro-entrepreneurs were sampled through snowball and convenience techniques. The findings showed that stepwise multiple regression analysis identified four models in the prediction of micro-entrepreneurial growth. Specifically, operational challenge $(\beta=-.35, p<.001)$, lack of support, $\beta=-.17, p<.001)$, workforce challenge $(\beta=.22, p<$ $.001)$, and personal factors $(\beta=-.21, p<.01)$ are significant predictors of micro-entrepreneurial growth. The findings were discussed in line with the literature while recommendations in terms of decision-making applications, and provision of developmental programs in assisting rural entrepreneurship for enhancement of growth were suggested.
\end{abstract}

Keywords: Micro-Entrepreneur; Growth; Rural Entrepreneurship; Operational Challenge

\section{INTRODUCTION}

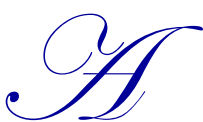

$\mathrm{s}$ research in entrepreneurship grows so is the continuous interest and further global recognition for entrepreneurship (Lin, Miao \& Nie, 2012). Given the growing significance of entrepreneurial activities, there are reasons to evaluate the existence of entrepreneurial challenges (Kim, 2011) especially among rural micro-entrepreneurs. This is because small businesses/micro-entrepreneurship are highly recognized as profitable sources of every financial establishment (Agyapong, Agyapong \& Darfor, 2011) and that rural environments face different obstacles from urban environments (Durr, Lyons, \& Lichtenstein, 2000). The existing business environments of small businesses in developing countries are overwhelmed by limitations and lack of consistency (Ahmad \& Xavier, 2012; Lan \& Wu, 2010, Sandhu, Sidique \& Riaz, 2011). These encounters continue to hinder small businesses operations because entrepreneurial activities in South Africa especially among rural communities continue to experience high failure rates (Olawale \& Garwe, 2010).

According to research, micro-enterprises are key to the livelihood and survival of several people in South Africa as well as in many developing economies (Herrington, Kew, \& Kew, 2010). While in many developed countries these businesses are considered marginal in their contribution to employment and GDP, in South Africa (as in many developing countries) these informal and micro enterprises are key to the livelihood and survival of millions of people. According to the 2008 Department of Trade and Industry report (DTI, 2008), the SMME sector grew by $27 \%$ of people between 2004 and 2007, with the most significant growth associated with medium-sized enterprises while the smallest growth occurred among micro enterprises. Similarly, the Provincial business distribution differs significantly with respect to formal/informal businesses, however, Northern Cape having contributes an extremely small number of businesses to the country's total, and the difference between formal/informal is marginal (DTI, 2008). The current study seek to understand the nature of challenges of rural entrepreneurship and its influence on micro-entrepreneurial growth in Northern Cape Province of South Africa. 
In this study, small business and micro-entrepreneurship are used interchangeably to refer to businesses that individuals offer as it consolidates resources, assumes risks and manages the businesses in return for financial gains, physical and psychological wellbeing. The knowledge derivable from this study is expected to aid decision-making processes or act as vital instrument to provide various forms of assistance to owner-mangers of small businesses in rural areas. Such knowledge can also serve as guiding tool towards the provisioning of developmental programs for rural micro-entrepreneurs.

\section{REVIEW OF LITERATURE}

Generally, entrepreneurial challenges differ in terms of labor law as well as existing regulatory framework (Jodyanne, 2009) as there are lot of formal procedures that business license applications go through before approval (Ngorora \& Mago, 2013) which could affect effective exploitation of business opportunities by rural micro-entrepreneurs. Challenges like this places micro-entrepreneurs on threats of harassments by law enforcement agencies as many try to operate businesses at unauthorized places (Chigunta, Schnurr, James-Wilson, \& Torres, 2005). Prior studies over the years have shown that establishing start-ups and operations are influenced by challenges such as funding (Das, 2012; Narayanasamy, Rasiah \& Jacobs, 2011; Young \& Flores, 2011), inability to access formal bank credits (Musara \& Fatoki, 2012; Nkuah, Tanyeh \& Gaeten, 2013) and the need for financial support towards increase in trading activities and growth (Fatoki \& Garwe, 2010). Other identified challenges include erratic government policy framework, lack of entrepreneurial education and training (Ahmad \& Xavier, 2012), political and economic instabilities, and poor infrastructure facilities that obstruct business operations (Chowdhury, 2007; Taomina \& Lao, 2007).

\section{Characteristics of Rural Areas}

The complex nature of rural environments cannot be left unnoticed. Rural areas can be identified through specific features such as existing human settlement spaces with little patches of landscape and mainly known for their geographical differences. Rural areas have markets that are too small when defined in terms of revenue, capital accumulation and numbers and service volumes (Mochrie \& Galloway, 2004; Lee \& Suzanne, 2000; Lyons, 2000). This probably explains why there is low trend for market products expansion by micro-entrepreneurs. Situation like this, is what Robinson, Dassie, and Christy (2004) described as geographic location impediment to entrepreneurship growth.

According to Stathopoulou, Psaltopoulos and Skuras (2004), the processes of entrepreneurship bear similarities in both rural and urban areas. The only difference is that small businesses and micro-entrepreneurial activities are characterized with declining population, dependency on natural resources for economic survival and distant marketing information. Hence, to generate entrepreneurial culture across rural communities, governments have called on private sector organizations to assist in strengthening micro-entrepreneurial activities and small business operations (Labrianidis, 2006). Researchers asserts that in less developed countries most small businesses lack critical resources such as business locations, limited access to technology, and access to reliable information for business funding (Adams, Khoja \& Kauffman, 2012; Ngassam, Kandie, Nkaelang \& Modibe, 2009), lack of adequate support services information to acquire loans (Mutezo, 2005; Rogerson, 2006). In addition, the business owners are unable to make an informed decision to deploy the relevant resources to sustain business operations (Burns, 2007; Alvarez, 2005). The inability to manage inventory efficiently limits business growth rate (Busuttil, 2007). Hence, most small businesses lack innovative drive due to dearth of other resources (Gill \& Nahum, 2012; Williams \& Williams, 2011). No wonder, Cacciolatti, Fearn and McNeil (2011) and Keh, Nguyen and Ng (2007), found positive relationships between information and business success.

Although it is generally believed that funding small businesses is not a South African problem alone a major concern in Sub-Saharan Africa (Fjose, Grunfeld \& Green, 2010). Therefore, small businesses are in dire need of financial assistance (Rankhumise, 2010) and education in the areas of knowledge and information (Bowen, Morara \& Mureithi, 2009) as banks and financial houses view small businesses to be of high risk venture (Nguyen \& Luu, 2013). Inadequate source of energy due to poor electricity supply growth (Herrington, et al., 2010) is the second and the most significant limitations to small businesses. Other identified factors are lack of adequate network for phone connections 
(Macueve, Mandlate, Ginger, Gaster \& Macome, 2009); lack of application of technology could help create positive impact (Ray, Barney, \& Muhanna, 2004); Xue, Offodile, \& Zhou, 2011); and higher infrastructure costs and due to insecure power supply (Akuru \& Okoro, 2014). Insecure power supply impact negatively more on small businesses in contrast to large firms; hence most of the small businesses closed their businesses (Moyo, 2012).

Business success is defined as a set of complex concepts that allows for business growth (Shane \& Venkataraman, 2000). Furthermore, business success means firm profitability and potential for business growth (Gronholt \& Martensen, 2009). The growth and development of business entails composite factors such as strategy, process and the business performance that works in harmony for the benefits of shareholders. Studies have indicated that business growth is difficult to evaluate in micro-enterprises due to the multiplicity of indicators - even more so in developing countries, where bookkeeping is scarce and secrecy towards the tax office is high (Babalola, 2010; McPherson, 1998). Therefore, perceived business growth format is used in this study due to the difficulties in obtaining quantitative indicator of entrepreneurial growth. Researchers also identified factors of management, marketing and access to funding as contributors to business success/growth (Brush, Ceru \& Blackburn, 2009), while Eisenhardt and Martin (2000) added that cooperative relationship with business clients contributed to business success/growth. Earlier McClelland (1961) suggested that successful entrepreneurs are expected to acquire strong decision-making and the need for personal achievement skills in order to create successful business growth. Herrington, Kew and Kew (2009) reported that successful business ventures growth were result of human, financial and social capitals. Thus, there is probability of high failure of small businesses with acute shortages of any of these capitals and other social networks support (Marshal \& Oliver, 2005). The framework involved the inclusion of predictor variables (such as specific, operational, financial challenges) on the criterion variable of business growth.

\section{It is therefore hypothesized that:}

Factor of operational challenges, skill development, lack of support, workforce challenge, personal and financial challenges will individually jointly contribute significantly to business growth.

\section{METHOD}

\section{Research Design and Statistical Analysis}

The study was based on cross-sectional survey research design to achieve the study objectives. IBM SPSS statistical package 23 version was used to generate descriptive statistics and also test the hypothesis using stepwise multiple regression analysis. The multivariate analysis was conducted to determine the relationship between the predictor variables of business challenges and operations, and the criterion variable of perceived business growth among microentrepreneurs.

\section{Data Collection and Participants}

Testing the hypotheses, data were collected among micro-entrepreneurs from two rural district municipalities (Frances Baard and John Taolo Gaetsewe) in the Northern Cape Province of South Africa through self-report questionnaire. Due to unavailability of reliable database of micro-entrepreneurs, the researchers, through snowball and convenience sampling methods get through to 400 participants. Despite the assurance of anonymity and confidentiality were guaranteed to encourage respondent's response rate only 282 participants were found useable. Response rate was approximately $70.5 \%$. Small businesses from the study areas are from industrial sectors such as transportation, retail and wholesale, fruits and vegetables, beauty salons, cell phone repairs services, Internet services, accommodation, and garden services among others.

\section{Measures}

The questionnaire was developed on the basis of information gathered from the literature on factors that impede rural entrepreneurship growth. Research questions were, as much as possible, kept clear and concise. The questionnaire comprises eight sections. 
Predictor variables: Operational challenges was an 8 -item scale constructed for the purpose of this study. This scale assessed respondents' business operational challenge (e.g. there is inadequate basic infrastructure - electricity, roads, and transportation; poor location of business premises"). High score in this scale indicate high level of operational challenge. The instrument demonstrates a high level of reliability with a Cronbach's alpha of 0.77 .

Skill development challenge was measured with 4-item scale. Participants rated their agreement with each statement on a 5-point scale. Cronbach alpha for the present sample was $\alpha=0.81$. The scale used five point, Likert type 'strongly agree' to 'strongly disagree' response format. Sample items include: "Unable to employ skillful employees"; and "Absence of small business education".

Lack of support challenge consisted of 4-item self-developed scale which was measured with a five-point Likert scale ranging from 1 to 5. Sample items include: "No resources to assist small businesses growth"; and "Local economic development does not focus on small businesses". The instrument demonstrates a high level of reliability with a Cronbach's alpha of 0.79 .

Workforce challenges was measured with a two-item self-developed scale. Sample items are "coping with ageing workforce"; "Inability to keep younger employees". The response was indicated on a Likert five point rating format. The instrument demonstrated a high level of reliability with a Cronbach's alpha of 0.73 .

Personal Challenge was measured with 4-item. Participants indicated how often they experienced each item on five point Likert scale ( $1=$ "strongly disagree' to $5=$ "strongly agree"). High score in this scale indicate high level of personal challenge. Sample item include "Time pressures because of work and family issues" and "Inability to prepare credible business plans for bank loans". The instrument showed a high level of reliability with a Cronbach's alpha of 0.78 .

Financial Challenge was measured with a 4-item statement which were presented using 5-point Likert-type scale from "strongly agree" to "strongly disagree". Sample items are "Too much costs of doing business on sole owner" and "Inadequate accounting and management skills" The instrument revealed a high level of reliability with a Cronbach's alpha of 0.74 .

Criterion variable: Business growth was measured using a self-developed scale. It is a 7-item scale with a Likert response ranging between "strongly disagree" and "strongly agree". The scale includes items such as "The business has experienced growth in profits (more money in my pocket) over the past few years', "The image of the business (how people see us), relative to our competitors, has grown over the past few years". Strongly disagree was scored 1 while strongly agree was scored 7; a higher score reflect greater business growth. The instrument demonstrates a high level of reliability with a Cronbach's alpha of 0.89 .

Demographic variable: The micro-entrepreneurs responded to questions regarding: age $(0=20-29$ years, $1=30-39$ years, $2=40-49$ years, $3=50-59$ years, $4=60+$ years $)$; gender $(0=$ male, $1=$ female $)$; marital status $(0=$ single, $1=$ married, 2 = divorce/widowed); educational qualification $(0=$ lower than matric, $1=$ Matric, $2=$ Certificate/trade skill, 3 = diploma, 4 = university degree); and years of self-employment (total number of years).

Prior to administering the questionnaires, the Likert-type questionnaires were pre-tested with some selected microentrepreneurs for minor corrections to enhance readability, validity and reliability of the questionnaires.

\section{RESULTS}

\section{Descriptive Statistics of Micro-Entrepreneurs}

The descriptive statistics revealed that $(63.47 \%)$ of participating micro-entrepreneur were males in contrast to only (35.46\%) females with majority ( $40.07 \%)$ of participants aged between 30 to 39 years followed by $(33.33 \%)$ for 40 to 49 age bracket while (10.28\%) of participants were within aged bracket 20 to 29 years. Most of micro-entrepreneurs were married (53.54\%), and single 38.65\%. Regarding educational achievements, most participating possessed 
certificate/Trade skilled (27.30\%); (23.05\%) received matric education while $(22.70 \%)$ obtained lower than matric qualifications.

Table 1. Descriptive statistics showing demographic variables of the micro-entrepreneurs.

\begin{tabular}{l|l|c|c}
\hline & Variables & $\mathbf{N}$ & Percentages \\
\hline \multirow{3}{*}{ Marital Status } & Single & 109 & $38.65 \%$ \\
\cline { 2 - 4 } & Married & 151 & $53.54 \%$ \\
\hline \multirow{2}{*}{ Gender } & Divorced & 18 & $6.37 \%$ \\
\hline \multirow{5}{*}{ Age } & Male & 179 & $63.47 \%$ \\
\cline { 2 - 4 } & Female & 100 & $35.46 \%$ \\
\hline \multirow{5}{*}{ Educational background } & 20 to 29 years & 29 & $10.28 \%$ \\
\hline & 30 to 39 years & 113 & $40.07 \%$ \\
\cline { 2 - 4 } & 40 to 49 years & 94 & $33.33 \%$ \\
\hline & 50 to 59 years & 36 & $12.76 \%$ \\
\cline { 2 - 4 } & $60+$ years & 8 & $2.83 \%$ \\
\hline & Lower than matric & 64 & $22.70 \%$ \\
\cline { 2 - 4 } & Matric & 77 & $23.05 \%$ \\
\cline { 2 - 4 } & Certificate/trade skills & 51 & $27.30 \%$ \\
\cline { 2 - 4 } & Diploma & 20 & $18.09 \%$ \\
\cline { 2 - 4 } & University degree & & $7.09 \%$ \\
\hline
\end{tabular}

\section{Regression Analysis}

The working hypothesis which stated that factors of skill development, operational challenge, workforce issues, lack of support, financial challenge and personal would independently and jointly predict perceived business growth was tested using stepwise multiple regression analysis. The results are presented in Table 2 above. Step 1 indicates that operational factors $(\beta=-.45, \mathrm{p}<.000)$ is the most obvious negative predictor of perceived business growth producing $20.1 \%$ variance, $\mathrm{F}(1,231)=57.94, \mathrm{p}<.000$.

Step 2 reveals that lack of support is the second most important predictor of perceived business growth with $23.1 \%$ variance explained by the predictors, $\mathrm{F}(2,230)=34.60, \mathrm{p}<.000$, indicating that addition of lack of support increased $3 \%$ of variance in perceived business growth. The results show that operational factors $(\beta=-.46, p<.000)$ significant negative predictor while lack of support $(\beta=-.18, \mathrm{p}<.001)$ have positive significant effect on perceived business growth.

Step 3 depicts that workforce issues is the third important predictor of perceived business growth with $25.8 \%$ variance explained by the predictors, $\mathrm{F}(3,229)=26.58, \mathrm{p}<.000$, showing that addition of workforce problem increased $2.7 \%$ of variance in perceived business growth. The results show that operational factors $(\beta=-.47, p<.000)$ and lack of support $(\beta=-.21, \mathrm{p}<.000)$ are significant negative predictors, whereas workforce issues $(\beta=.17, \mathrm{p}<.001)$ has significant positive effect on perceived business growth. 
Table 2. Stepwise regression analysis showing the influence of predictor variables on perceived business growth.

\begin{tabular}{l|c|c}
\hline \multicolumn{1}{c|}{ Predictor } & $\Delta \mathbf{R}^{2}$ & $\mathbf{B}$ \\
\hline Step 1 & .20 & $-.45^{* * *}$ \\
\hline Operational factor & & $-.46^{* * *}$ \\
\hline Step 2 & .03 & $-.18^{* *}$ \\
\hline Operational factors & & $-.47^{* * *}$ \\
\hline Lack of support & & $-.21^{* * *}$ \\
\hline Step 3 & .03 & $.17^{* *}$ \\
\hline Operational factors & & $-.35^{* * *}$ \\
\hline Lack of support & & $-.17^{* * *}$ \\
\hline Workforce & .02 & $.22^{* * *}$ \\
\hline Step 4 & & $-.21^{* *}$ \\
\hline Operational factors & & \\
\hline Lack of support & & \\
\hline Workforce & & \\
\hline Personal factors & & \\
\hline
\end{tabular}

Step 4 depicts personal challenges as the least important predictor of perceived business growth with $28.1 \%$ variance explained by the predictors, $\mathrm{F}(4,228)=22.29, \mathrm{p}<.000$, showing that addition of personal challenge increased $2.3 \%$ of variance in perceived business growth. The results show that operational factors $(\beta=-.35, p<.000)$, lack of support $(\beta=-.17, \mathrm{p}<.01)$ and personal challenges $(\beta=-.21, \mathrm{p}<.01)$ are significant negative predictors of perceived business growth, whereas workforce issues $(\beta=.22, \mathrm{p}<.000)$ has significant positive effect on perceived business growth. In sum, the findings indicate that operational factors and lack of support are the strongest most explanatory factors in explaining perceived business growth.

\section{DISCUSSIONS AND CONCLUSION}

The findings from the analysis performed to determine the factors influencing business growth among microentrepreneurs in rural areas showed factors ranging from operational, lack of support, workforce and personal challenges. It could be assumed therefore that awareness of challenges might be a greater steps towards growing a successful enterprise if such identified issues are properly addressed.

Specifically, the findings showed that operational challenge were the most significant contributor to microentrepreneurial growth. Thus confirming previous studies which found inability to make informed decision as hampering sustain business operations (Burns, 2007; Alvarez, 2005); inability to manage inventory efficiently (Busuttil, 2007); lack critical resources such as business locations, limited access to technology, and access to reliable information for business funding (Adams, et al., 2012; Ngassam, et al., 2009), and lack innovative drive (Gill \& Nahum, 2012; Williams \& Williams, 2011), all of which limits business growth. This finding from this study concurred with researches, which identified factors of severe shortages of energy (Macueve, et al, 2009; Sahlfeld, 2007), inadequate source of energy (Herrington, et al, 2010), poor electricity supply and lack of adequate network for phone connections (Macueve, et al., 2009), higher infrastructure costs and application of technology could help create positive impact (Akuru \& Okoro, 2014; Ray, et al., 2004; Xue, et al., 2011) and insecure power supply (Moyo, 2012) as significant impediment to rural micro-entrepreneurial growth.

The issues of personal factors as an impediment to business growth indirectly confirmed McClelland (1961) suggestion that successful entrepreneurs are expected to acquire strong need for personal achievement skills in order to create successful business growth. This implies that though personal development in terms of skills and educational can be complex and time-consuming, it has beneficial effects on small businesses/micro-entrepreneurial activities (Urban \& Van Vuuren, 2008). The current study which identified workforce challenge, and lack of support as part of significant factors in the prediction of micro-entrepreneurial growth confirmed the assertion of Herrington, et al (2009) that successful business ventures growth were result of human, financial and social capitals; the acute shortage of these and social network support might result in failure entrepreneurial failure according to (Marshal \& Oliver, 2005). Further support for the findings came from the studies of Mutezo (2005), and Rogerson (2006) which found that lack of adequate support services hindered information to acquire loans.

Copyright by author(s); $\underline{\text { CC-BY }}$ 


\section{IMPLICATIONS AND RECOMMENDATIONS}

This study made significant attempt to empirically examine the factors impeding business growth through exploratory means. Generally, this study offered both theoretical and practical opportunities in enhancing operations of rural small businesses. First, it is hoped that this generated information will assist in the development of adequate and more robust theory in explaining rural entrepreneurial success, which can be of interest for further study. The study showed that personal factors were very influential on micro-entrepreneurial growth which is why it would be interesting to focus on individual programs that would assist rural entrepreneurs develop needed coping mechanism in improving their business growth and better outcomes.

The governmental and developmental agencies can be of help in assisting rural entrepreneurs through the provision of developmental programs, which can enhance rural entrepreneurship growth and survival. Specifically, overcoming the issue of infrastructure accessibility and training to support the management of small business will go a long way in the helping rural entrepreneurs. Above all, there is a need for collaborative approach involving the individual entrepreneurs, entrepreneurial associations and government agency for meaningful network in solving naughty and complex barriers. In addition, this strategy is more likely to impact and improve the self-esteem and efficacy of the entrepreneurs as they will have opportunity to learn how others are coping and also think strategically which at the end benefit their business growth.

Rural entrepreneurs should be provided with advice, guidance, and knowledge as well as coaching in the management of business as one of the key areas identified (Bowen, et al., 2009) and also they should be equipped with skills in financial management (Rankhumise, 2010). For these, it is recommended that centers should be created to provide mentoring-mentorship program for rural micro-entrepreneurs to enable them work with other entrepreneurs. Training of existing and aspiring micro-entrepreneurs should complement existing skills and the most pressing needs.

\section{AUTHOR BIOGRAPHIES}

Albert Tchey Agbenyegah is a PhD holder in Busniess Management and a Senior Lecturer at the Department of Management, Faculty of Management Sciences, Durban University of Technology, Riverside Campus. His research focuses on broadly on Business management and entrepreneurship.

Sunday Samson Babalola, is a Professor in the Department of Human Resource Management, School of Management Sciences, University of Venda. He is a South African Rated Scientist. His research interests focus on, business performance, entrepreneurship, workplace attitude, human capital management and organizational behavior.

\section{REFERENCES}

Adams, H. J., Khoja, M. F., \& Kauffman, P. (2012). An empirical study of buyer-supplier relationship within small business organization. Journal of Small Business Management, 50(1), 20-40.

Agyapong, D., Agyapong, G. K. Q., \& Darfor, K. N. (2011). Criteria for assessing small and medium enterprises' borrowers in Ghana. International Business Research, 4(4), 132-138.

Ahmad, Z. S., \& Xavier, R. S. (2012). Entrepreneurial environments and growth: Evidence from Malaysia GEM data. Journal of Chinese Entrepreneurship, 4(1), 50-64.

Akuru, U. B., \& Okoro, O. I. (2014). Economic implications of constant power outages on SMEs in Nigeria. Journal of Energy in Southern Africa, 25(3), 61-66.

Alvarez, S. A. (2005). Resources and hierarchies: Intersections between entrepreneurship and business strategy. In Z. J. Acs \& D. B. Audretsch (Eds.), Handbook of entrepreneurship research: An interdisciplinary survey and introduction (pp. 247263). New York: Springer.

Babalola, S. S. (2010). The role of socio-psychological capital assets on identification with self-employment and perceived entrepreneurial success among skilled professionals. Journal of Small Business and Entrepreneurship, 23(2), $159-172$.

Bowen, M., Morara, M. \& Mureithi, S. (2009). Management of business challenges among small and micro enterprises in Nairobi-Kenya. KCA, Journal of Business Management, 2(1), 16- 31.

Brush, C. G., Ceru, D. J., \& Blackburn, R. (2009). Pathways to entrepreneurial growth: The influence of management, marketing, and money. Business Horizons, 52(6), 481- 491.

Burns, P. (2007). Entrepreneurship and small business ( $2^{\text {nd }}$ ed.). Basingstoke, UK: Palgrave Macmillan.

Copyright by author(s); $\underline{\text { CC-BY }}$ 
Busuttil, J. (2007). An analysis of the retail credit environment. The Seminar of Malta Association of credit Management, Western Dragonara, 9 March, 1-20.

Cacciolatti, L., Fearn, A., \& McNeil, D. (2011). Empirical evidence for a relationship between business growth and the use of structured marketing information amongst food and drink SMEs. Academy of Marketing Conference, 5-7 July. University of Kent, UK.

Chigunta, F., Schnurr, J., James-Wilson, D., \& Torres, V. (2005). Being "real" about youth entrepreneurship in eastern and southern Africa, SEED Working Paper No. 72, Geneva: ILO.

Chowdhury, M. S. (2007). Overcoming entrepreneurship development constraints: The case of Bangladesh. Journal of Enterprising Communities: People and Places in the Global Economy, 1(3), 240-251.

Das, S. (2012). Entrepreneurship through micro finance in northeast India: A comprehensive review of existing literature. Information Management and Business Review, 4(4), 168-184.

Department of Trade and Industry (2008). Annual Review of Small Business in South Africa, 2006-2007: National Skills Research Agency (NASRA), Jobworx.

Durr, M., Lyons, T. S., \& Lichtenstein, G. A. (2000). Identifying the unique needs of urban entrepreneurs: African American skill set development. Race and Society, 3, 75-90.

Eisenhardt, K. M. \& Martin J. A. (2000). Dynamic capabilities: what are they? Strategic Management Journal, 21(11), 11051121.

Fatoki, O., \& Garwe, D. (2010). Obstacles to the growth of new SMEs in South Africa: A principal component analysis approach. African Journal of Business Management, 4(5), 729- 738.

Fjose, S., Grunfeld, L. \& Green, C. (2010). SMEs and growth in sub-Saharan Africa: Identifying SMEs roles and obstacles to SMEs growth. MENON Publication No. 14, MENON Business Economics.

Gill, A., \& Nahum, B. (2012). Barriers to small business growth in Canada. Journal of Small Business and Enterprise Development, 19(4), 656-668.

Gronholdt, L., \& Martensen, A. (2009). Management practices driving sustained business success. Measuring Business Excellence, 13(1), 47-55.

Herrington, M., Kew J., \& Kew, P. (2009). Global entrepreneurship monitor: South African executive report. University of Cape Town: Graduate School of Business.

Herrington, M., Kew, J., \& Kew, P. (2010). Tracking entrepreneurship in South Africa: A GEM perspective. University of Cape Town: Graduate School of Business.

Jodyanne, K. (2009). Motivational factors in a push-pull theory of entrepreneurship. Gender in Management: An International Journal, 24(5), 346-364.

Keh, H. T., Nguyen, T. T. M., \& Ng, H. P. (2007). The effects of entrepreneurial orientation and marketing information on the performance of SMEs. Journal of Business Venturing 22, 592- 611.

Kim, Y. (2011). SMEs in Africa: Challenges and the role of government for the future. South Africa: Consultancy Africa Intelligence (CAI).

Labrianidis, L. (2006). Fostering entrepreneurship as a means to overcome barriers to development of rural peripheral areas. In T. D. N. Vaz, E. Morgan, \& P. Nijkamp (Eds.), The new European rurality: Strategies for small firms. Aldershot: Ashgate Publishing.

Lan, Q., \& Wu, S. (2010). An empirical study of entrepreneurial orientation and degree of internationalization of small and medium-sized Chinese manufacturing enterprises. Journal of Chinese Entrepreneurship, 2(1), 53-75.

Lee, S. M., \& Suzanne, P. J. (2000). Culture, entrepreneurial orientation and global competitiveness. Journal of World Business, 35(4), 401-416.

Lin, S., Miao, Q., \& Nie, K. (2012). A case study on entrepreneurship for sustained innovation. African Journal of Business Management, 6, 493-450.

Lyons, T. (2000). Policies for creating an entrepreneurial region. University of Lovisville: CREED.

Macueve, G., Mandlate, J., Ginger, L., Gaster, P., \& Macome, E. (2009). Women's use of information and communication technologies in Mozambique: A tool for empowerment. In I. Buskens \& A. Webb (Eds.), African women and ICT's: Investigating technology, gender and empowerment. Pretoria: UNISA.

Marshal, M. I., \& Oliver, W. N. (2005). The effects of human, financial, and social capital on the entrepreneurial process for entrepreneurs in Indiana. Paper presented at the Allied Social Science Associations Annual Meeting, Philadelphia, PA, January 7-9.

McClelland, D. (1961). The achieving society. New Jersey: Van Nostrand.

McPherson, M. A. (1998). Zimbabwe: A third nationwide survey of micro and small enterprises. Washington: U.S. Agency for International Development.

Mochrie, R., \& Galloway, L. (2004). Motivations for business start-up in Scotland. Paper presented at the Agriculture Economics Society 78th Annual Conference, London.

Moyo, B. (2012). Do power cuts affect productivity? A case study of Nigerian manufacturing firms. International Business and Economics Research Journal, 11(10), 1163-1174. 
Musara, M. \& Fatoki, O. O. (2012). Access to finance in the SME sector: A South African perspective. Asian Journal of Business Management, 4(1), 58- 67.

Mutezo, A. T. (2005). Obstacles in the access to SMME finance: An empirical perspective on Tshwane. Pretoria: University of South Africa.

Narayanasamy, K., Rasiah, D., \& Jacobs, C. J. (2011). An empirical study of factors influencing gender differences in entrepreneurship. International Business and Economics Research Journal, 10(10), 17 - 29.

Ngassam, E. K., Kandie, W., Nkaelang, B., \& Modiba, F. (2009). Towards an e-model for the enhancement of service rendering by SMMEs supporting agencies in South Africa. Proceedings of IST-Africa conference, May 6-8, Uganda, Kampala.

Ngorora, G. P. K., \& Mago, S. (2013). Challenges of rural entrepreneurship in South Africa: Insights from Nkonkobe Municipal Area in the Eastern Cape Province. International Journal of Information Technology and Business Management, 16(1), $1-11$.

Nguyen, N., \& Luu, N. (2013). Determinants of financing patterns and access to formal and informal credit. The case of small and medium-sized enterprises in Vietnam. Journal of Management Research, 5(2), 240-259.

Nkuah, J., Tanyeh, J. P., \& Gaeten, K. (2013). Financing Small and Medium Enterprises (SMEs) in Ghana: Challenges and determinants in accessing bank credit. International Journal of Research in Social Sciences, 2(3), 2-25.

Olawale, F., \& Garwe, D. (2010). Obstacles to the growth of new SMEs in South Africa: A principle component analysis approach. African Journal of Business Management, 4(5), 729-738.

Rankhumise, E. M. (2010). Lessons and challenges faced by small business owners in running their businesses. Proceedings of the IAMB conference, January 25-27. Las Vegas, California.

Ray, G., Barney, J. B., \& Muhanna, W. A. (2004). Capabilities, business processes and competitive advantage: Choosing the dependent variable in empirical tests of the resource- based view. Strategic Management Journal, 25(1), 23-38.

Robinson, K. L., Dassie, W., \& Christy, R. D. (2004). Entrepreneurship and small business development as a rural development strategy. Conference proceedings Tuskegee University. Tuskegee: Alabama

Rogerson, C. M. (2006). The market development approach to SMME development: Implication for Local Government in South Africa. Urban Forum, 17(1), 54 - 78.

Sahlfeld, M. (2007). How does ICT work for development? A review of the challenges and opportunities. ATDF Journal, 4(1), 22-36.

Sandhu, M. S., Sidique, S. F. \& Riaz, S. (2011). Entrepreneurship barriers and entrepreneurial inclination among Malaysian postgraduate students. International Journal of Entrepreneurial Behavior and Research, 17(4), 428 - 449.

Shane, S., \& Venkataraman, S. (2000). The promise of entrepreneurship as a field of research. Academy of Management Review, 25(1), 217-226.

Stathopoulou, S., Psaltopoulos, D. \& Skuras, D. (2004). Rural entrepreneurship in Europe: a research framework and agenda. International Journal of Entrepreneurial Behavior and Research, 10(6), 404- 425.

Taormina, R. J., \& Lao, S. K. M. (2007). Measuring Chinese entrepreneurial motivation, personality and environmental influences. International Journal of Entrepreneurial Behavior and Research, 13(4), 200- 221.

Urban, B., vanVuuren, J., \& Barreira, J. D. (2008). High-growth entrepreneurs: The relevance of business knowledge and work experience on venture success. Journal of Contemporary Management, 5(1), 58 - 71.

Williams, N., \& Williams, C. (2011). Tackling barriers to entrepreneurship in a deprived urban neighborhood. The Journal of the Local Economy Policy Unit, 26(1), 30 - 42.

Xue, G., Offodile, O. F., Zhou, H., \& Troutt, M. D. (2011). Integrated production planning with sequence-dependent family setup times. International Journal of Production Economics, 131(2), 674 - 681.

Young, M., \& Flores, I. (2011). Characteristics and needed assistance of Hispanic women business owners: Emerging entrepreneurs. Small Business Institute Journal, 7, 80 -105. 


\section{NOTES}

